Original Article

\title{
KNEE CAP: A MORPHOMETRIC STUDY IN DRY HUMAN PATELLA
}

\author{
Preeti Agarwal ${ }^{\star}$, Archana Singh ${ }^{\star *}$, Rakesh Gupta ${ }^{* \star *}$ \\ *Department of Anatomy, Varun Arjun Medical College \& Rohilkhand Hospital, Banthra, Shahjahanpur, UP, India \\ ${ }^{* *}$ Department of Anatomy, Rohilkhand Medical Collage \& Hospital, Bareilly, UP, India
}

\begin{abstract}
Introduction: Patella is the largest sesamoid bone. Knowledge of dimensions and of classification of patellae is very important anthropologically as well as clinically for total knee arthroplasty and harvesting techniques of patellar ligament grafts. Since there are very few studies on patella, present study aimed to do morphometry of patella.

Material \& Methods: Morphometric measurements were done on 60 dry patellae of both sexes, using digital sliding Vernier caliper. All statistical analysis was done with help of standard SPSS software. Student t-test was used to ascertain whether significant difference exist between right and left patella. Patella was also classified into one of three categories according to Koyuncu's classification-Type A (WMAF=WLAF), Type B (WMAF <WLAF) and Type $\mathrm{C}$ (WMAF>WLAF).

Results: Out of 60 patellae, 34 patellae were of right side and 26 were of left side. Mean patellar height was $39.53 \pm 5.58$; mean width of patella $41.27 \pm 3.67$ and mean patellar thickness was $19.84 \pm 1.76$. Width of medial articular facet was $17.50 \pm 1.88$ and width of lateral articular facet was $20.82 \pm 2.72$. There was no significant difference in measurements of right and left patella except width for lateral articular facet where $p$ value was $<0.01$. In present study, according to Koyuncu's classification $86.66 \%$ patella were of class B type, $13.34 \%$ patella were of class $\mathrm{C}$ type while class $\mathrm{A}$ type patella was not found. The secondary ridge was found to be conspicuous in $23.3 \%$ patellae.

Conclusion: Present study on morphometry of the patella is obviously very important and concluded parameters can be variably used in anthropology and anthropometrics, comparative anatomy and evolutionary biology, patellofemoral unit prosthesis synthesis, patellar implants, arthroplasty and forensic sciences.
\end{abstract}

Keywords: Patella, sesamoid bone, knee arthroplasty.

\section{INTRODUCTION}

Patella is also known as Knee Cap. Patella is the largest sesamoid bone. It is found embedded in the tendon of quadriceps femoris. It lies anterior to distal femur (femoral condyles). It has two surfaces anterior and posterior, three borders superior, medial and lateral and an apex which points inferiorly (Fig. 1). The anterior surface is separated from skin by a prepatellar bursa and covered by an expansion of upcoming tendons of quadriceps femoris. The posterior surface is divided into two parts, superior (articulating) and inferior (non-articulating). The superior part of the posterior surface is crossed by a smooth vertical ridge, which fits into the intercondylar groove on femoral patellar surface, which divides this area into lateral and medial facet. The lateral facet is usually larger. Medial and lateral facets are further divided by faint horizontal lines into equal thirds. A seventh odd facet is present as a narrow strip along the medial border of patella; it contacts the medial femoral condyle in extreme flexion. The inferior part forms the apex of patella which provides attachment to the patellar ligament [1].

\section{Address for Correspondence:}

Dr. Archana Singh, Assistant Professor, Department of Anatomy, Rohilkhand Medical Collage \& Hospital,

Bareilly-243006, Uttar Pradesh, India. | Mob:+919935462440 Email: drarchana279@gmail.com 


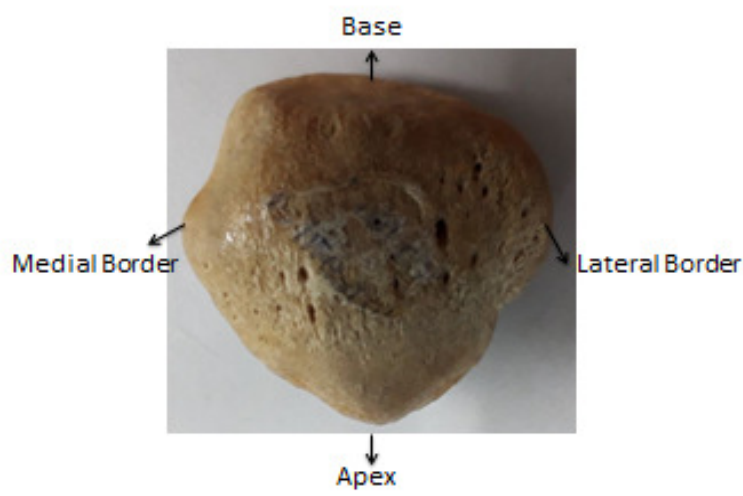

Fig. 1: Anterior view of left patella

Knowledge of dimensions and of classification of patellae is very important anthropologically as well as clinically. It is involved in the various movements of knee and methods of sitting and squatting. Therefore, there may be effect of cultural and ethnic variables on patellar morphology. It is to be assumed that the size of the patella, can be dependent on the strain generated by the quadriceps muscle as it lies within the tendon of quadriceps. But the absence of patella in some animals with powerful action of knee joint, led to controversy concerning with this concept [2].

It was revealed that the geometry of the patella and patellar tendon was significantly larger in males and other demographic factors including weight, height, body mass index well correlates with patellar thickness, but poor correlation with the length of patellar tendon $[3,4]$. Quadriceps tendon thickness also showed significant correlation with patellar height [5].

Koyuncu et al. (2011), studied the patellar development during the fetal life and found that there are no significant differences between genders or sides (right versus left patellae). However, a significant correlation was found between gestational age and all studied morphometric parameters of patella [6].

Many pathologies may affect the patellofemoral compartment of the knee joint including: osteoarthritis, chondromalacia, fractures, idiopathic and patellofemoral pain syndrome etc. [7]. Patients undergoing total knee arthroplasty (TKA) are routinely subjected to a pre-determined amount of post-surgical loading of the knee, to preserve patellar articular cartilage and subchondral bone trophism [8]. Other problems may occur during which TKA include patellofemoral instability and implant's failure [9].
Biomechanical disturbances can also affect the patellofemoral compartment of the knee $[10,11]$.

Knowledge of morphology and dimensions of patella perform very important role in designing of prosthesis and development of surgical techniques.

\section{MATERIAL AND METHODS}

This study was carried out on 60 dry patellae of unknown sex, obtained from Department of Anatomy, Varun Arjun Medical College \& Rohilkhand Hospital, Banthra and Rohilkhand Medical College \& Hospital, Bareilly. Specimens having signs of fracture, pins and plates or the specimen having loss of bone density or bad erosion were excluded from study. All the measurements were taken by using digital sliding Vernier caliper up to $0.001 \mathrm{~mm}$ accuracy. All measurements were taken twice at different time to exclude human error. Data was tabulated and analysis was done with help of standard SPSS software. Student t-test was used to ascertain whether significant difference exist between right and left patella.

Following parameters were measured by digital Vernier caliper (Fig. 2):

1. Patella Height (PH): Linear distance measured between the superior border and the apex of patella.

2. Patella Width (PW): Linear distance measured between the medial and lateral border of patella.

3. Patella Thickness (PT): measured as linear distance between the anterior surface of patella and the median ridge present on posterior surface of patella.

4. Width of Medial Articular Facet (WMAF): measured as maximum width from the medial border to medial ridge of patella.

5. Width of Lateral Articular Facet (WLAF): measured as maximum width from lateral border to median ridge of patella.

6. Median Ridge Thickness (RT): measured as width of median ridge.

Patella was also classified into one of three categories according to Koyuncu's classification as Type A (WMAF $=\mathrm{WLAF})$, Type $\mathrm{B}(\mathrm{WMAF}<\mathrm{WLAF})$ and Type $\mathrm{C}$ (WMAF>WLAF). The presence and predisposition of secondary ridge was also carefully noted. 


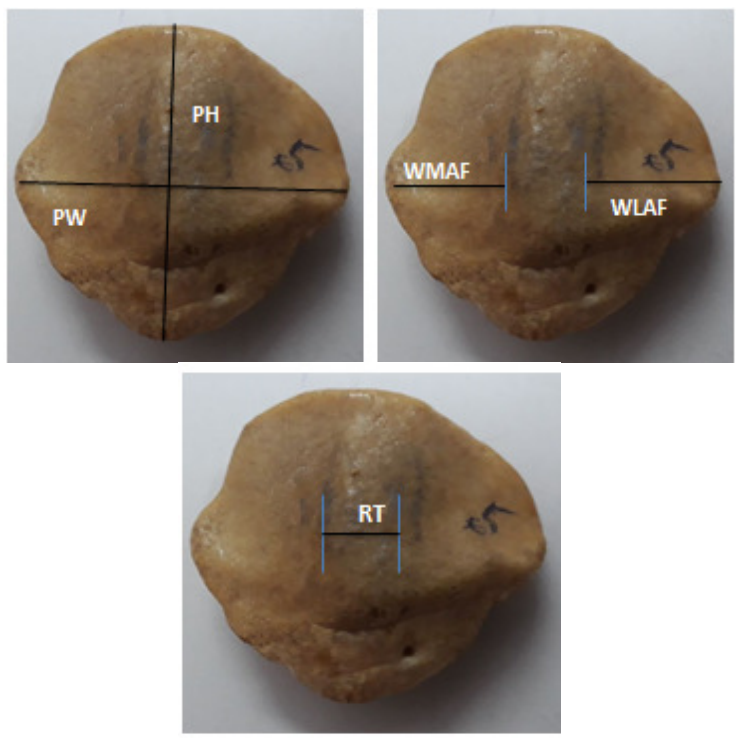

Fig. 2: Parameters measured by digital Vernier caliper. PHPatellar height, PW-Patellar width, WMAF- width of medial articular facet, WLAF- width of lateral articular facet, RTmedian ridge thickness

\section{RESULTS}

In the present study, out of 60 patellae 34 patellae were of right side and 26 were of left side. Mean patellar height was $39.53 \pm 5.58$; mean width of patella $41.27 \pm 3.67$ and mean patellar thickness was $19.84 \pm 1.76$. Width of medial articular facet was
$17.50+1.88$ and width of lateral articular facet was $20.82 \pm 2.72$. Mean thickness of median ridge was $7.48 \mathrm{~mm} \pm 1.37$ (Table 1).

Measurements of right and left patella, their tvalue and $p$-value were analyzed. In present study, there was no significant difference in measurements of right and left patella except width for lateral articular facet where $p$ value is $<0.01$ (Table 2, Fig. 3)). In present study, according to Koyuncu's classification $86.66 \%$ patella were of class B type, $13.34 \%$ patella were of class $C$ type (Fig. 4 \& 5)) while class A type patella was not found in present study. Secondary ridge was found prominent in 6 patellae (Fig. 6) and indistinct in 28 patella of right side whereas on left side it was distinct in 8 patellae and indistinct in 18 patellae (Fig. 7).

Table 1: Mean values of patellar measurements

\begin{tabular}{|l|c|c|}
\hline \multicolumn{1}{|c|}{ Parameters } & Mean $(\mathbf{m m})$ & $\begin{array}{c}\text { Standard } \\
\text { Deviation (SD) }\end{array}$ \\
\hline Patella Height & 39.53 & 5.58 \\
\hline Patella Width & 41.27 & 3.67 \\
\hline Patella Thickness & 19.84 & 1.76 \\
\hline Width of medial articular Facet & 17.50 & 1.88 \\
\hline Width of lateral articular Facet & 20.82 & 2.72 \\
\hline Ridge Thickness & 7.48 & 1.37 \\
\hline
\end{tabular}

Table 2: Mean, maximum \& minimum values along with $t$ and $p$-values of different parameters of patella

\begin{tabular}{|c|c|c|c|c|c|c|c|c|}
\hline \multirow[t]{2}{*}{ Parameters } & \multicolumn{3}{|c|}{ Right patella $(\mathrm{N}=34)$} & \multicolumn{3}{|c|}{ Left patella $(\mathrm{N}=26)$} & \multirow{2}{*}{$\begin{array}{c}\text { t- } \\
\text { value }\end{array}$} & \multirow{2}{*}{$\begin{array}{c}p \text {-value } \\
\text { (significant } \\
p<0.05 \text { ) }\end{array}$} \\
\hline & $\underset{(\mathrm{mm})}{\operatorname{Mean} \pm \mathrm{SD}}$ & $\begin{array}{l}\text { Maximum } \\
\quad(\mathrm{mm})\end{array}$ & $\underset{(\mathrm{mm})}{\operatorname{Minimum}}$ & Mean $\pm S D$ & $\begin{array}{l}\text { Maximum } \\
(\mathrm{mm})\end{array}$ & $\underset{(\mathrm{mm})}{\operatorname{Minimum}}$ & & \\
\hline Patella height & $40.51 \pm 2.96$ & 45.02 & 35.08 & $38.24 \pm 7.68$ & 48.86 & 15.73 & 1.46 & 0.16 \\
\hline Patella width & $42.04 \pm 2.69$ & 46.70 & 38.06 & $40.26 \pm 4.51$ & 47.13 & 33.53 & 1.74 & 0.10 \\
\hline Patella Thickness & $20.10 \pm 1.48$ & 23.10 & 18.14 & $19.49 \pm 2.05$ & 23.42 & 16.43 & 1.25 & 0.22 \\
\hline $\begin{array}{l}\text { Width of Medial } \\
\text { Articular Facet }\end{array}$ & $17.28 \pm 1.91$ & 19.62 & 13.90 & $17.78 \pm 1.86$ & 20.24 & 13.93 & 0.72 & 0.48 \\
\hline $\begin{array}{l}\text { Width of Lateral } \\
\text { Articular Facet }\end{array}$ & $21.43 \pm 2.22$ & 25.45 & 17.70 & $20.03 \pm 3.13$ & 23.96 & 15.18 & 2.63 & $0.01^{*}$ \\
\hline Ridge Thickness & $7.65 \pm 1.46$ & 9.91 & 4.67 & $7.25 \pm 1.22$ & 9.32 & 5.68 & 1.08 & 0.30 \\
\hline
\end{tabular}




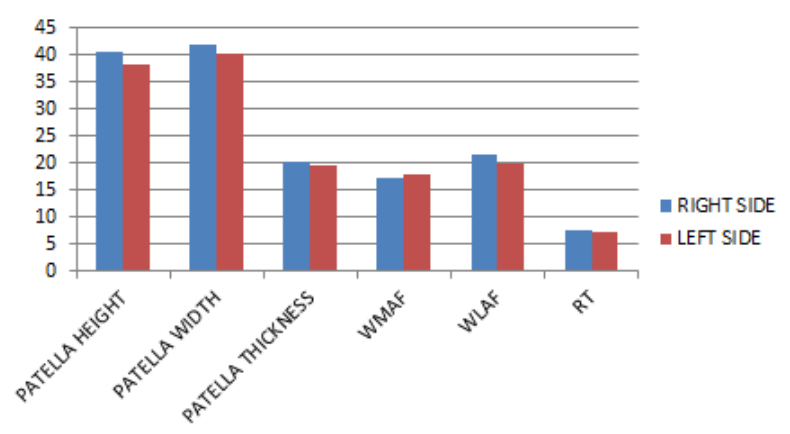

Fig. 3: Measurements of different parameters of patella on right and left side

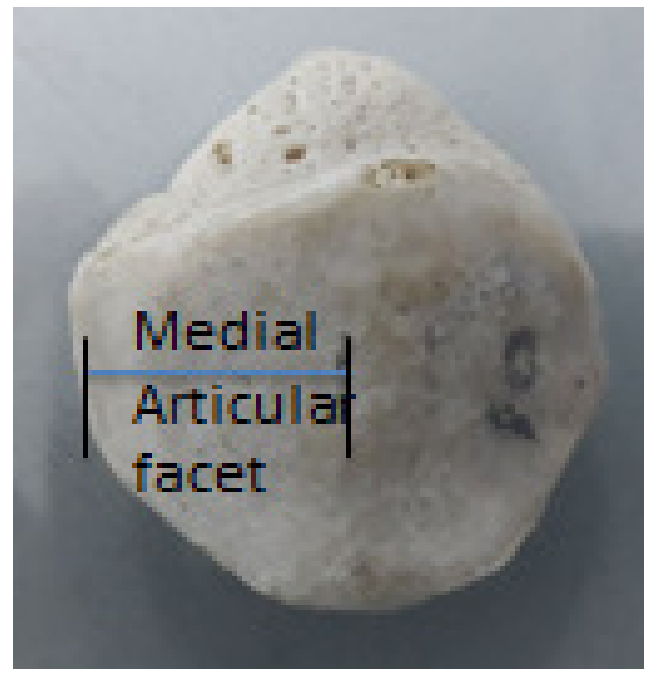

Fig. 4: Class $C$ type patella: width of medial articular facet is more than width of lateral articular facet

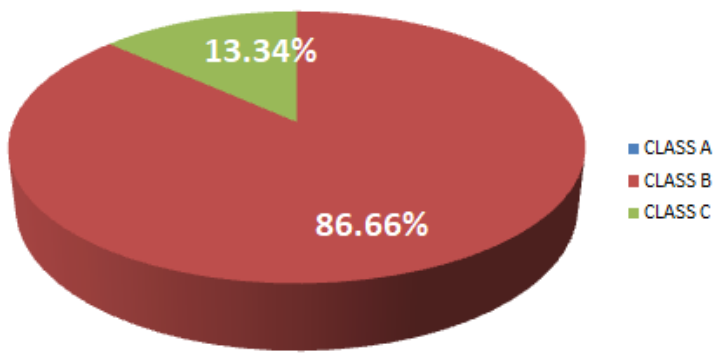

Fig. 5: Classification of patellae according to Koyuncu's classification

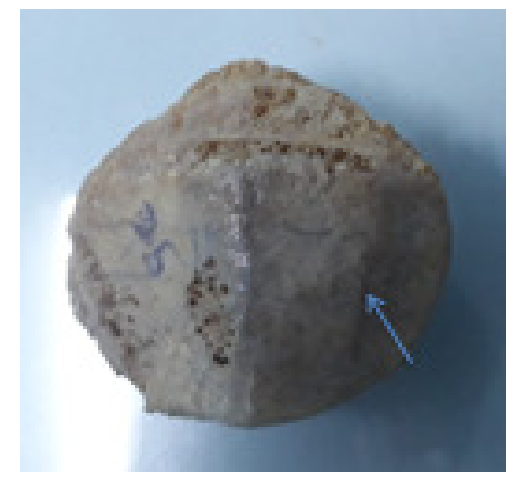

Fig. 6: Conspicuous secondary ridge (arrow)

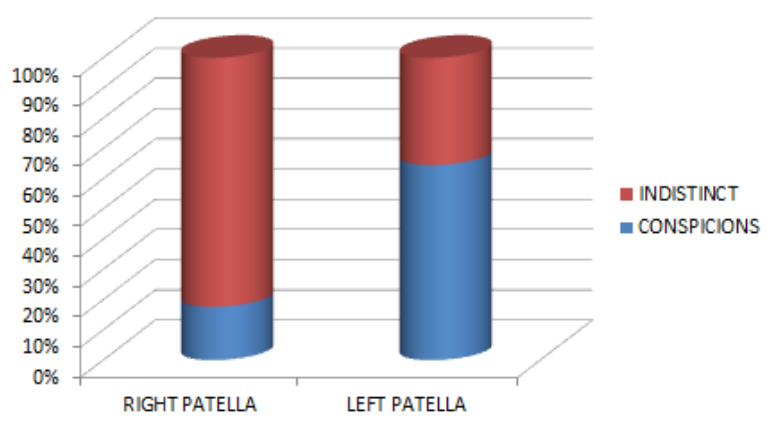

Fig. 7: Prominence of secondary ridge in patellae of right and left side

\section{DISCUSSION}

In previous studies, different measuring techniques were studied, like measurements taken with use of radiographs and measurements taken during knee arthroplasty. But all of these methods have some limitations and have more chances of errors. In our study, measurements have been taken on bones which are totally cleared from other muscles and tissues to avoid measurement errors. These measurements could be very beneficial for surgeries of knee and for anthropological records.

In present study, mean patellar height was $39.53 \mathrm{~mm} \pm 5.58$, mean patellar width $41.27 \mathrm{~mm} \pm 3.67$ and mean patellar thickness was $19.84 \mathrm{~mm} \pm 1.76$ which was similar to values reported by Vohra (2017) [12] but less than the findings of Yoo et al. (2007) [4] Schlenzka and Schwesinger (1990) [13], Iranpour et al. (2008) [14], Oladiran et al. (2013) [15] and Kayalvizhi et al. [16]. Morphometric measurements of patellae of present study was higher than the study of Agnihotri et al. (2013) [2] (Table 3, Fig. 8). 
Table 3: Comparison of patellar dimensions with previous studies

\begin{tabular}{|l|c|c|c|c|c|c|}
\hline \multicolumn{1}{|c|}{ Authors } & \multicolumn{2}{c|}{$\begin{array}{c}\text { Patella } \\
\text { Height }\end{array}$} & \multicolumn{2}{c|}{$\begin{array}{c}\text { Patella } \\
\text { Width }\end{array}$} & \multicolumn{2}{c|}{$\begin{array}{c}\text { Patella } \\
\text { Thickness }\end{array}$} \\
\cline { 2 - 7 } & Mean & S.D. & Mean & S.D. & Mean & S.D. \\
\hline $\begin{array}{l}\text { Yoo et al. (2007) } \\
\text { [4] }\end{array}$ & 44.6 & 3.7 & 45.8 & 3.6 & 22.3 & 1.9 \\
\hline $\begin{array}{l}\text { Schlenzka and } \\
\text { Schwesinger } \\
\text { (1990) [13] }\end{array}$ & 54.4 & 3.5 & 50.3 & 4 & - & - \\
\hline $\begin{array}{l}\text { Iranpour et al. } \\
\text { (2008) [14] }\end{array}$ & 34.3 & 4.8 & 44.8 & 4.8 & 22.4 & 2.3 \\
\hline $\begin{array}{l}\text { Baldwin and } \\
\text { House (2005) [17] }\end{array}$ & 43.7 & 3.6 & 45.1 & 3.9 & 23.9 & 2.1 \\
\hline $\begin{array}{l}\text { Oladiran et al. } \\
\text { (2013) [15] }\end{array}$ & 42.9 & 4.8 & 42.1 & 3.1 & 19.7 & 1.1 \\
\hline $\begin{array}{l}\text { Kayalvizhi et al. } \\
\text { [16] }\end{array}$ & 45.8 & - & 37 & - & 16.95 & - \\
\hline $\begin{array}{l}\text { Agnihotri et al. } \\
\text { (2013) [2] }\end{array}$ & 35.1 & & 22.6 & \\
\hline $\begin{array}{l}\text { Vohra P (2017) } \\
\text { [12] }\end{array}$ & 41.55 & 2.84 & 40.17 & 2.59 & 19.29 & 1.52 \\
\hline $\begin{array}{l}\text { Present study } \\
\text { (2018) }\end{array}$ & 39.53 & 5.58 & 41.27 & 3.67 & 19.84 & 1.76 \\
\hline
\end{tabular}

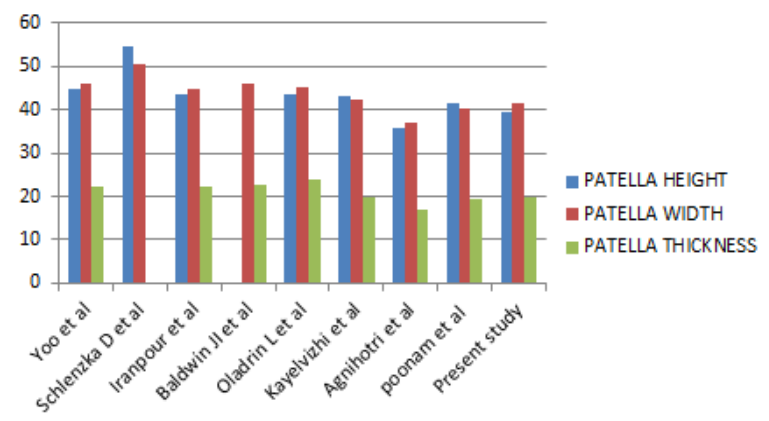

Fig. 8: Comparison of patellar dimensions with previous studies

In present study, mean of width of medial articular facet was less than the mean width of lateral articular facet. On comparison of WLAF of right and left side, significant difference was found $(p<0.05)$. WMAF < WLAF was also reported by Oladiran et al. (2013) and Murugan et al. (2017) [15,18] (Table 4).
Table 4: Comparison of width of medial and lateral articular facets

\begin{tabular}{|c|c|c|c|c|c|c|}
\hline \multirow[t]{2}{*}{ Authors } & \multicolumn{3}{|c|}{$\begin{array}{l}\text { Width of medial } \\
\text { articular facet }\end{array}$} & \multicolumn{3}{|c|}{$\begin{array}{l}\text { Width of lateral } \\
\text { articular facet }\end{array}$} \\
\hline & $\underset{\text { SD }}{\operatorname{Mean} \pm}$ & $\begin{array}{l}\mathrm{t}- \\
\text { value }\end{array}$ & $\begin{array}{c}\mathrm{p}- \\
\text { value }\end{array}$ & $\underset{\text { SD }}{\text { Mean } \pm}$ & $\begin{array}{c}t- \\
\text { value }\end{array}$ & $\begin{array}{c}\mathrm{p}- \\
\text { value }\end{array}$ \\
\hline $\begin{array}{l}\text { Oladiran et al. } \\
\text { (2013) [15] }\end{array}$ & $\begin{array}{c}20.38 \\
\pm .36\end{array}$ & 0.54 & 0.59 & $\begin{array}{c}26.02 \\
\pm \pm \\
2.68\end{array}$ & 0.54 & 0.59 \\
\hline $\begin{array}{l}\text { Murugan et al. } \\
(2017) \text { [18] }\end{array}$ & $\begin{array}{c}18.78 \\
+ \\
1.95\end{array}$ & 0.28 & 0.78 & $\begin{array}{c}22.75 \\
+ \\
2.66\end{array}$ & 0.97 & 0.33 \\
\hline $\begin{array}{l}\text { Present study } \\
(2018)\end{array}$ & $\begin{array}{c}17.50 \\
\pm \\
1.88\end{array}$ & 0.72 & 0.48 & $\begin{array}{c}20.82 \\
\pm \\
2.72\end{array}$ & 2.63 & .01 \\
\hline
\end{tabular}

In the present study, the width of the medial articular facet was $17.50 \mathrm{~mm}$ which was almost similar to the studies done on other populations like Chinese [19], Koreans [4] and Westerns [17] in whom the values of WMAF were $19.03 \mathrm{~mm}, 18.4 \mathrm{~mm}$ and $18.8 \mathrm{~mm}$ respectively. Similarly the width of the lateral articular facet in present study was $20.82 \mathrm{~mm}$ while $25.1 \mathrm{~mm}$ in Chinese [19], 23.3mm in Koreans [4] and 25.3mm in Westerns [17] respectively.

In a study about the classification of patellae of fetal cadavers, Koyuncu et al. (2011) reported that $20 \%$ of patellae were in class A (width of medial articular facet and lateral articular facet were equal). Class $B$ (the width of the MAF was smaller than the width of LAF) was reported as the most prevalent i.e. $50 \%$ while $30 \%$ of patella was of type C (width of MAF was greater than width of LAF) [6]. In the present study, it was found that the Type B patella was the most prevalent, which is in support of previous observations by Fucentese et al. (2006) and Murugan et al. $(2017)[18,20]$.

The secondary ridge was found to run obliquely in a generally longitudinal direction closer to the median ridge proximally than distally. This ridge may develop after birth in response to functional loads applied to knee. The secondary ridge was less prominent compared to the primary patellar ridge. There is considerable individual variation in prominence of the secondary ridge and in present study the secondary ridge was found to be conspicuous in $23.3 \%$ patellae while Agnihotri et al. (2013) reported it in $14 \%$ cases [2]. Variations in morphometric values of patella; reported by various authors, might be due to geographical and racial variation. 


\section{CONCLUSION}

Present study on morphometry of the patella is obviously very important from a biomechanical perspective. Although the sample size of present study is less but the concluded parameters and their relevant statistical analysis, can be variably used in Anthropology and anthropometrics, comparative Anatomy and evolutionary Biology, patellofemoral unit prosthesis synthesis, patellar implants, arthroplasty, biomedical and biomechanical applications, Surgical and radiological indices, orthopedics and arthroscopy, rheumatology, and forensic sciences.

\section{REFERENCES}

1. Standring S. Gray's Anatomy. The Anatomical Basis of Clinical Practice. $40^{\text {th }}$ ed. p 1394.

2. Agnihotri G, Kaur R, Kalyan GS. Patellar shape, nose pattern and facet configuration in 200 North. Int J Curr Res Rev. 2013 5 (14): 30-35.

3. Miller TT, Staron RB, Feldman F. Patellar height on sagittal MR imaging of the knee. AJR Am J Roentgenol. 1996; 167(2): 33941.

4. Yoo JH, Yi SR, Kim JH. The geometry of patella and patellar tendon measured on knee MRI. Surg Radiol Anat. 2007; 29(8): 623-8.

5. Potage D, Duparc F, D'Utruy A, Courage O, Roussignol X. Mapping the quadriceps tendon: an anatomic and morphometric study to guide tendon harvesting. Surg Radiol Anat. 2015; 37(9):1063-7.

6. Koyuncu E, Cankara N, Sulak O, Özgüner G, Albay S. The morphometry of patella and patellar ligament during the fetal period. Clin Anat. 2011; 24(2):225-31.

7. Gunardi AJ, Brennan SL, Wang Y, Cicuttini FM, Pasco JA, Kotowicz MA, Nicholson GC, Wluka AE. Associations between measures of adiposity over 10 years and patella cartilage in population-based asymptomatic women. Int J Obes. 2013; 37(12): 1586-9.
8. Denaro V, Forriol F, Di Martino A, Papalia R. Modifications of patellar articular cartilage and subchondral bone following immobilisation and denervation: a histologic and morphometric in vivo study. J Orthop Trauma. 2004; 5(1): 44-9.

9. Kelly MA. Patellofemoral complications following total knee arthroplasty. Instructional course lectures. 2000; 50: 403-7.

10. Martín MD, Santiago FR, Calvo RP, Álvarez LG. Patellofemoral morphometry in patients with idiopathic patellofemoral pain syndrome. Eur J Radiol. 2010; 75(1): 64-7.

11. Lund F, Nilsson BE. Radiologic evaluation of chondromalacia patellae. Acta Radiol Diagn. 1979; 21(3): 413-6.

12. Vohra P. Morphometric study of patella and its role in sex determination. International Journal of Anatomy Physiology and Biochemistry. 2017; 4 (3):6-9.

13. Schlenzka D, Schwesinger G. The height of the patella: An anatomical study. E J Radiol. 1990; 11:19-21.

14. Iranpour F, Merican AM, Cobb JP, Amis AA. The width: thickness ratio of the patella: An aid in knee arthroplasty. Clin Orthop Relat Res. 2008; 466:1198-1203.

15. Oladiran I, Olateju OI, Philander I, Bidmos MA. Morphometric analysis of the patella and patellar ligament of South Africans of European ancestry. S Afr J Sci. 2013; 109(9-10): 01-6.

16. Kayalvizhi I, Arora S, Dang B, Bansal S, Narayan RK. Sex determination by applying discriminant functional analysis on patellar morphometry. $\mathrm{MH} ; 42(4.8)$ : 38-1.

17. Baldwin JL, House CK. Anatomic dimensions of the patella measured during total knee arthroplasty. J Arthroplasty. 2005; 20: $250-257$.

18. Murugan M, Ambika S, Nim VK. Knee Cap: A morphometric study. Int J Anat Res. 2017; 5(1):3556-59.

19. Shang $P$, Zhang L, Hou Z, Bai X, Ye X, Xu Z, Huang X. Morphometric measurement of the patella on $3 D$ model reconstructed from CT scan images for the southern Chinese population Chin Med J. 2014;127(1):96-101.

20. Fucentese SF, Von Roll A, Koch PP, Epari DR, Fuchs B, Schottle PB. The patellar morphology in trochlear dysplasia- A comparative MRI study. Knee, 2006; 13:145-150. 